\title{
Implementasi Safety Management System \\ di Bandar Udara Internasional Radin Inten II Pada Masa Pandemi Covid -19
}

\author{
M. Indra Martadinata, Herlina Febiyanti, Viktor Suryan, Randa Agusta Pratama, Hani \\ Adhwa Nabilah \\ Politeknik Penerbangan Palembang, \\ * e-mail: indrakoe@ poltekbangplg.ac.id
}

\begin{abstract}
Abstrak
Tujuan Penelitian ini adalah untuk mengetahui implementasi safety management system (sms) di Bandar Udara Internasional Radin Inten II Lampung pada masa pandemi Covid-19. Metode yang digunakan adalah metode deskriptif dengan pendekatan kualitatif dimana peneliti melakukan pendalaman implementasi safety management system di Bandar Udara Internasional Radin Inten II Lampung pada masa pandemi Covid- 19, kemudian melihat tanggapan personil terkait efektifitasnya di bandara. Faktor pendukung yaitu: Kebijakan Perusahan yang mendukung perlindungan dan keselamatan karyawannya, Penyediaan sarana dan prasarana dalam penanganan virus corona. Pemanfaatan inovasi melalui penyediaan aplikasi berbasis teknologi, pelaksanaan sosialisasi keselamatan dan kesehatan di dalam dan daerah sekitar bandara. Faktor penghambat yaitu: Struktur organisasi yang masih sederhan ditambah dengan adanya pembatasan jam operasional penerbangan, masyarakat yang belum terbiasa dengan pelaksanaan protocol kesehatan, meningkatnya potensi hazard di saat pandemi terutama musim hujan. Implikasinya adalah perusahaan agar selalu melaksanakan pelatihan tanggap darurat demi mempersiapkan personil yang siap di masa pandemi covid-19.
\end{abstract}

Kata Kunci: Covid 19, safety management system, bandar udara, implementasi, pandemi, hazard

\section{PENDAHULUAN}

Awal tahun 2020 adalah suatu awal yang cukup berat bagi dunia termasuk Indonesia. Hal ini terjadi karena diakhir tahun 2019 muncul penyakit yang menjadi wabah yaitu Sars Cov-2 atau yang lebih dikenal Covid-19. Virus Influenza ini muncul pertama kali di China lebih tepatnya di kota Wuhan. Dengan gejala awal berupa demam, batuk dan sesak napas maka, untuk pasien dengan gejala lebih parah yaitu sulit bernafas atau nafas pendek, nyeri atau sakit pada bagian dada, pusing atau tidak dapat berdiri menggerakkan tubuh, bibir atau badan tampak membiru (octiviani $\mathrm{v}, 2020)$. Tanpa menunggu lama penyebaran virus covid-19 menyebar keseluruh dunia, menghentikan seluruh aktivitas manusia, dan dunia pun dilanda Pandemi. Seluruh negara melakukan segala cara untuk mencegah penularan virus ini. Menurut data WHO, yang dikutip Kompas tanggal 5 September 2020 jumlah orang di dunia yang terinfeksi corona adalah 27 juta dan untuk Indonesia terkonfirmasi sebanyak 194.109 orang per tanggal 6 September 2020 (Gugus Tugas Covid-19, 2020).

Transportasi udara merupakan salah satu sektor yang terkena dampak pandemi, berupaya untuk tetap berjalan normal dengan 
ditetapkannya pelonggaran aturan dengan tidak menetapkan pembatasan operasi bagi sektor transportasi, namun tetap memberlakukan pengawasan dalam menjalankan aturan-aturan protocol kesehatan yang mengacu pada aturan WHO (World Health Organization) dan di tindak lanjuti oleh Gugus Tugas Percepatan Penanganan Bencana. Kementerian Perhubungan melalui Direktorat Perhubungan Udara memberikan peraturan penanganan Covid-19 guna diterapakan di bandarabandara. PT Angkasa Pura II (persero) selaku operator bandar udara di Indonesia, mengelola Bandar Udara Internasional Radin Inten II Lampung juga sebagai salah satu penggerak roda ekonomi bidang transportasi udara turut terkena dampak pandemi covid-19 ini.

Lalu lintas udara di Bandar Udara Radin Inten II selama 10 (sepuluh) tahun terakhir terjadi peningkatan jumlah penumpang di sektor transportasi udara, hal ini dkarenakan gencarnya promosi pariwisata dan masuknya investasi di provinsi Lampung.

Tabel 1. Data Arus Lalu Lintas Udara Bandar Udara Radin Inten II

\begin{tabular}{|c|c|c|c|c|c|c|}
\hline No & $\begin{array}{l}\text { Tahu } \\
\mathrm{n}\end{array}$ & $\begin{array}{l}\begin{array}{c}\text { Pesawat } \\
\text { (flight) }\end{array} \\
\end{array}$ & $\begin{array}{c}\text { Penumpang } \\
\text { (orang) }\end{array}$ & $\begin{array}{c}\text { Bagasi } \\
(\mathrm{kg})\end{array}$ & $\begin{array}{c}\text { Barang/Cargo } \\
(\mathrm{kg})\end{array}$ & Ket. \\
\hline 1 & 2010 & 6.442 & 732.135 & 5.093 .760 & 1.039 .114 & \\
\hline 2 & 2011 & 9.658 & 1.034 .050 & 6.702 .395 & 2.468 .654 & \\
\hline 3 & 2012 & 10.172 & 1.200 .666 & 7.639 .443 & 2.720 .078 & \\
\hline 4 & 2013 & 10.130 & 1.188 .110 & 7.933.272 & 3.043 .025 & \\
\hline 5 & 2014 & 9.768 & 1.229 .792 & 8.927 .452 & 3.726 .774 & \\
\hline 6 & 2015 & 12.001 & 1.419 .342 & 8.859 .067 & 4.436 .830 & \\
\hline 7 & 2016 & 16.989 & 1.928 .016 & $\begin{array}{c}11.915 .89 \\
2\end{array}$ & 4.877 .805 & \\
\hline 8 & 2017 & 21.749 & 2.463 .703 & $\begin{array}{c}14.160 .74 \\
0\end{array}$ & 5.580 .101 & \\
\hline 9 & 2018 & 21.108 & 2.643 .225 & $\begin{array}{c}15.968 .67 \\
4\end{array}$ & 5.859 .597 & \\
\hline 10 & 2019 & 15.850 & 1.865 .048 & 9.320 .958 & 3.585 .881 & \\
\hline 11 & 2020 & 5.142 & 381.517 & 953.735 & 949.549 & $\begin{array}{l}\text { Janu } \\
\text { ari } \\
\text { s.d } \\
\text { Agus } \\
\text { tus } \\
2020\end{array}$ \\
\hline
\end{tabular}

Sumber. Kantor UPBU Radin Inten II, 2020

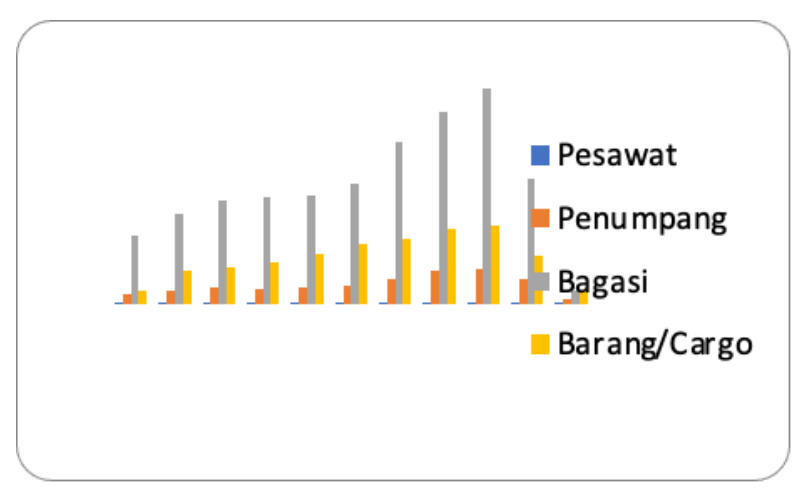

Gambar 1. Grafik Lalu Lintas Angkutan Udara Bandar Udara Radin Inten II dari tahun 2010 s.d 2020

Memasuki tahun 2020, terlihat di tabel terjadi penurunan jumlah penumpang dan barang kargo dikarenakan pengaruh pendemi covid-19 yang terjadi di Indonesia, yang berdampak langsung ke provinsi Lampung. Kebijakan yang dikeluarkan oleh pemerintah terkait Pembatasan Sosial Berskala Besar (PSBB) di Ibukota, yang mengakibatkan pembatasan pergerakan transportasi udara yang dikelola oleh PT Angkasa Pura II (persero) dan Bandar Udara lainya. PT Angkasa Pura II (persero) cabang Radin Inten II melakukan langkah-langkah efisiensi yaitu pembatasan jam operasi Bandar udara, semula beroperasi dari jam 06.00 WIB sampai dengan 21.00 WIB menjadi 09.00 WIB sampai 18.00 WIB.

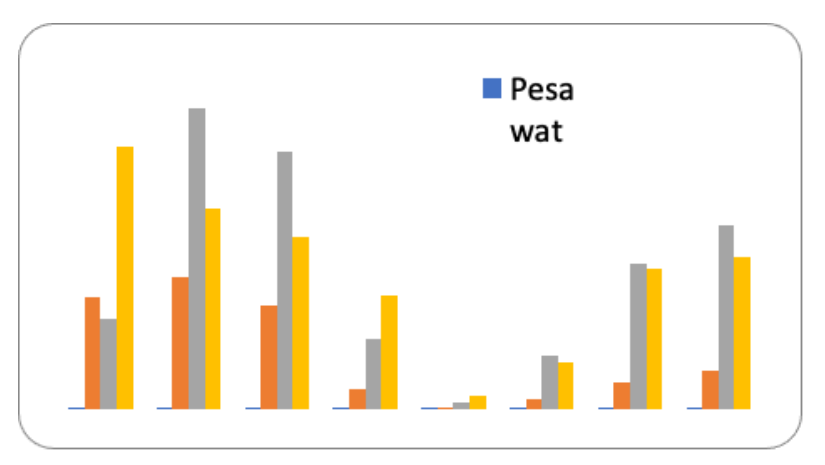

Gambar 2. Grafik Lalu Lintas Angkutan Udara Bandar Udara Internasional Radin Inten II Sepanjang Tahun 2020

Sumber. Dokumentasi Peneliti, 2020 
Penurunan aktivitas pergerakan pola lalu lintas angkutan udara di Bandar Udara Internasional Radin Inten II Lampung, pada masa covid-19 pada grafik ditunjukkan pada bulan Mei 2020, dimana pada bulan tersebut banyak faktor diantaranya adalah bulan puasa dan lebaran $1441 \mathrm{H}$ dimasa covid-19, dimana Pemerintah memberlakukan edaran bagi Aparatur Sipil Negara (ASN) dan karyawan BUMN untuk tidak mudik dimasa Covid-19.

Secara umum penurunan jumlah penumpang dan kargo pesawat berdampak pada penurunan keuntungan PT Angkasa Pura II secara umum dimana pada kuartal I ditahun 2019 dari 4,43 triliun rupah turun menjadi 3,21 triliun di awal semester I tahun 2020 dikutip pada laman berita kumparan.com tanggal 10 Agustus 2020. (https://www.kumparan.com/kumparanbisnis/t erdampak-corona-angkasa-pura-i-dan-iikompak-rugi-1tyLRXHMeDv/full).

Kenaikan jumlah pasien Covid-19 di Lampung menyebabkan penurunan jumlah penumpang dan penurunan jumlah trafik penerbangan dari dan menuju Lampung. Gugus Tugas Covid-19 Provinsi Lampung, melaporkan bahwa jumlah pasien yang terinfeksi covid-19 sebanyak 488 orang dengan jumlah kematian sebanyak 22 orang. (https://www.covid19.lampungprov.go.id/) dan data ini akan terus bertambah seiring dengan belum ditemukannya vaksin virus tersebut.

Dikutip dari laman berita www.sonora.id menyatakan bahwa "Provinsi Lampung adalah salah satu provinsi yang tidak menerapkan pola Pembatasan Sosial Berskala Besar (PSBB)." https://www.sonora.id/read/422110444/takakan-terapkan-psbb-gubernur-lampungkarena-tidak-menguntungkan?page=all,

2020). Padahal banyak provinsi menerapkan PSBB guna antisipasi langkah penyebaran virus dan mengurangi jumlah pasien. Namun menurut Gubernur Lampung, pilihan ini dipilih karena Lampung merupakan pintu gerbang pulau Sumatera yang apabila ditetapkan PSBB, maka akan menghambat kegiatan ekonomi lainnya. Bandar udara Internasional Radin Inten II ,sejak bulan Oktober tahun 2019 resmi dikelola oleh PT Angkasa Pura II (Persero) dengan skema pola Kerja Sama Pemanfaatan (KSP), sudah menerapkan Safety Management
System yang baik dan terprogram dalam pelaksanaan operasi Bandar udara.

Penanggung Jawab Kebijakan Safety Management System berubah pengelolaannya yaitu dari Kantor Unit Penyelenggara Bandar Udara Radin Inten II kepada PT. Angkasa Pura II (persero) dimana penanggung jawab pelaksana SMS sebelumnya adalah Kepala Bandar Udara menjadi Executive General Manager. Executive General Manager wajib membuat pernyataan terkait Komitmen Keselamatan dan dibuktikan dengan penanda tanganan Surat Komitmen tersebut.

Undang-undang Nomor 1 tahun 2009 tentang Penerbangan, yang mengamanahkan penerapan safety management system di dunia penerbangan Indonesia, lewat peraturan turunannya dibuat Peraturan Menteri yang mewajibkan operator Bandar udara mengelola Safety Management System secara berkala dan terus menerus agar menciptakan budaya keselamatan (safety culture) utamanya di bidang industri penerbangan. Untuk implementasi peraturan tersebut, pelaksanaannya dimulai sejak tahun 2011 untuk Bandar udara Internasional dan 2010 bagi Bandar udara Domestik.

Upaya dan inovasi yang dilakukan PT. Angkasa Pura II (persero) menerapkan suatu pelayanan dengan aplikasi teknologi yang mudah dan cepat dalam pengelolaan resiko keselamatan penerbangan. Pihak manajemen Bandar Udara Radin Inten II telah melakukan antisipasi dan pencegahan penularan virus covid 19 di Bandar udara dengan cara penyediaan alat ukur suhu dan penyediaan tempat guna pengendalian penyebaran virus corona berkoordinasi dengan stakeholder terkait. Namun, sampai saat ini masih banyak penumpang yang terkendala dalam peraturanperaturan yang berlaku di Bandar udara selama masa pandemi covid-19 ini.

Safety Management System sebagai salah satu syarat pemenuhan operasi di bandar udara wajib dipenuhi oleh pihak Angkasa Pura II (persero) sebagai pengelola bandar udara. Pemenuhan Safety Management System juga berdampak pada suatu pemenuhan Sertifikat Bandar Udara (SBU). Sejak dilaksanakannya Perjanjian Kerjasama Pemanfaatan (KSP) Direktorat Perhubungan Udara dengan PT Angkasa Pura II (Persero) sebagai pengelola 
Bandar Udara Internasional Radin Inten II, maka dokumen administrasi yang menyangkut pengoperasian juga berubah redaksinya.

Situasi pandemi yang sedang terjadi di Indonesia, maka Implementasi Safety Management System di bandar udara akan mengalami perubahan dan penyesuaian di era new normal tak terkecuali Bandar Udara Internasional Radin Inten II Lampung.

Atas dasar latar belakang inilah maka penulis mengangkat judul penelitian "Implementasi Safety Management System di Bandar Udara Internasional Radin Inten II Pada Masa Pandemi Covid 19”.

\section{METODE}

Penelitian ini dilaksanakan dengan menggunakan metode desriptif dengan pendekatan kualitatif, dimana menekankan pada upaya eksplorasi dilokasi penelitian tentang implementasi safety management system di Bandar Udara Internasional Radin Inten II. Penelitian ini adalah bersifat eksplorasi, sehingga tujuannya tidak untuk menguji hipotesis atau membuat suatu generalisasi. Pada rancangan penelitian ini didasarkan pada fokus masalah yang diteliti, kesesuaian antara objek penelitian dengan acuan teori, informan, instrumen, prosedur pengumpulan data dan analisis data. Moleong (2013) berpendapat penelitian kualitatif dilakukan untuk memahami fenomena tentang apa yang dialami oleh subjek penelitian dengan cara deskripsi dalam bentuk kata-kata dan bahasa, pada suatu konteks yang alamiah dan memanfaatkan berbagai metode ilmiah. Keabsahan data dilakukan dengan triangulasi sumber. Danim (2002) menyatakan bahwa suatu penelitian kualitatif menuntut penelaahan secara mendalam dari peneliti, tidak hanya sekedar mendengar mengenai apa dan bagaimana penelitian kualitatif, akan tetapi juga mampu memahami sepenuhnya dengan demikian diketahui proses kerja ilmiah dapat menghasilkan produk yang memenuhi kriteria objektif.

Penelitian ini dilaksanakan di Bandar Udara Internasional Radin Inten II Lampung dengan waktu pelaksanaan selama 6 bulan dari bulan Juli 2020 sampai dengan Desember
2020. Pengambilan data langsung dilaksanakan pada tanggal 25 Oktober 2020 sampai dengan 28 Oktober 2020. Data yang dikumpulkan adalah data primer dan data sekunder. Data primer adalah data yang diambil pada saat itu yaitu wawancara kepada informan dan data sekunder adalah data-data dokumentasi yang merupakan data dukung penelitian seperti laporan dan foto-foto dokumentasi pelaksanaan kegiatan.

\section{HASIL PEMBAHASAN}

\section{Pengadaan Alat Pelindung Diri (APD)}

Pemerintah mengeluarkan peraturan pada masa pandemi Covid -19 yaitu, peraturan pembatasan jam operasi yaitu dengan dikeluarkannya surat peraturan Menteri Perhubungan Nomor PM 18 Tahun 2020 tentang Pengendalian Transportasi dalam rangka Pencegahan Penyebaran Corona Virus Disease 2019 (covid-19), maka unit safety risk and quality control PT Angkasa Pura II Kantor Cabang Radin Inten II, sebagai perpanjangan tangan dari Executive General Manager mendapatkan tugas yaitu mengawasi dan mendata kebutuhan Alat Pelindung Diri (APD) bagi para karyawan di setiap Kantor Cabang untuk dilaporkan ke Kantor Pusat untuk diadakan secara rutin. Penegasan aturan tersebut adalah didasarkan atas Surat Direktorat Jenderal Perhubungan Udara Nomor AU.201/3/II/DJPU.DKP-2020 tanggal 2 Maret 2020 perihal Peningkatan Pemeriksaan Virus Corona (COVID-19) di Bandara dan Surat Direktorat Jenderal Perhubungan Udara Nomor AU.201/6/2/DJPU.DKP-2020 tanggal 18 Maret 2020 perihal Prosedur Pemeriksaan Keamanan Selama Pandemi Covid-19 dimana dalam pelaksanaan kegiatannya setiap personil keamanan wajib melengkapi diri dengan alat pelindung diri serta sarung tangan berbahan latex. Sehingga atas dasar itulah, kantor pusat menerbitkan Surat Nota Dinas ND.3858/DH/00/03/2020 perihal Peningkatan Kewaspadaan dan Pencegahan Penyebaran Infeksi COVID-19, maka cabang Bandara Radin Inten II melalui kantor pusat PT Angkasa Pura II menunjuk unit Safety Risk And Quality Control untuk mendata dan melaporkan keadaan kebutuhan APD di tiap 
unit operasi guna pengadaan APD dan penyediaan vitamin/suplemen bagi karyawan. Disamping itu juga penyiapan fasilitas bilik desinfektan, fasilitas cuci tangan dan fasilitas hand sanitizer, serta penjadwalan penyemprotan desinfektan di area publik.

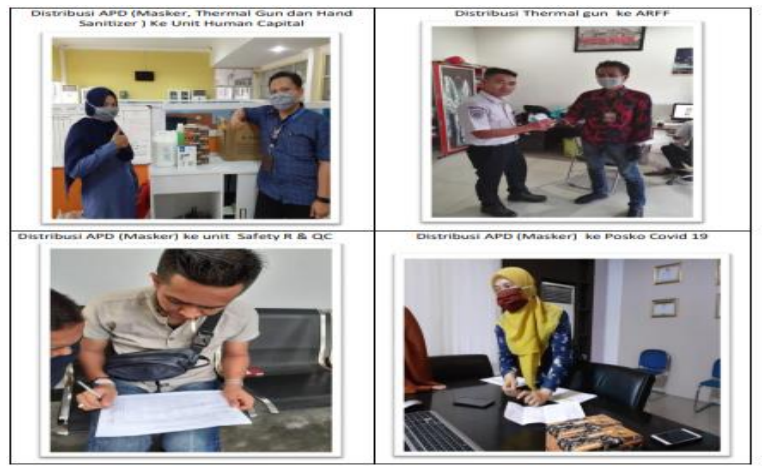

Gambar 3. Beberapa kegiatanpenanggulangan Pandemi Covid-19 di Bandar Udara.

Pihak Perusahaan turut mendukung kegiatan pemerintah dalam penanggulangan pandemi Covid-19, seperti mengeluarkan beberapa peraturan direksi yang bertujuan untuk memberikan kenyamanan dan perlindungan karyawan dalam bekerja. Berikut ini kami sajikan tabel peraturan yang telah diterbitkan. Fasilitas lainnya adalah penyediaan tempat Alat Pelindung Diri (APD) yang diletakkan di area keberangkatan (check in) dan di ruang kedatangan (arrival), dimaksudkan agar mempersiapkan personil keamanan dalam menghadapi keadaan darurat, apabila ditemukan penumpang yang terkonfirmasi COVID-19 berada dalam ruang tersebut dan butuh penanganan yang cepat dan terkontrol. Adapun peletaknnya berada di dalam lemari dan dilakukan pengawasan oleh pihak Safety Risk and Quality Control.Didalam tempat penyimpanan tersebut berisi APD yang terdiri atas: Sepatu Boot, Baju Hazmat, Safety Gloves, Masker dan Face Shield. Sedangkan standarisasi alat pelindung diri bagi kayawan PT Angkasa Pura II (persero) secara umum disyaratkan sebagai berikut:

Untuk face shield merupakan pelindung wajah umumnya terbuat dari plastic jernih transparan, yang memproteksi wajah sampai ke dagu dan merupakan mampu memproteksi wajah petugas ketika berhadapan dengan penumpang.
Bahan Visor PET food grade dengan ketebalan $0,1 \mathrm{~mm}$ sampai dengan $0,3 \mathrm{~mm}$ dengan ukuran PxL $24 \mathrm{~cm}$ x $17 \mathrm{~cm}$ double size protection film. Bahan frame flexible/ lentur

Untuk sarung tangan disyaratkan terbuat dari bahan nitrile (non latex), tanpa bedak dengan warna reguler biru, sarung tangan ini juga merupakan pelindung petugas dari kontak cairan infeksius selama bekerja, idealnya tahan robek, tahan bocor, dan biocompatibility ( tidak toksik) dan pas di tangan, Sedangkan untuk Masker bedah 3 Ply merupakan masker bedah yang terdiri dari 3 lapisan material dari bahan non woven (tidak dijahit), loose-fitting, dan sekali pakai untuk menciptakan penghalang fisik antara mulut dan hidung pengguna dengan kontaminan potensial di lingkungan terdekat sehingga efektif untuk memblokir percikan (droplet) dan tetesan dalam partikel besar, karet masker tidak mudah putus, SNI 8488:2018, memiliki efisiensi filtrasi bakteri $\geq 98 \%$, Tekanan diferensi $\mathrm{mmH} 0 / \mathrm{cm}^{2}<5.0$, Efisiensi filtrasi partikulat sub micron 0,1 mikron, $\% \geq 98$, Resistensi terhadap penetrasi oleh darah sintesis, tekanan minimum dalam mmHg untuk hasil ui 160 dan sebaran api Kelas 1. Semua persyaratan ini dituangkan kedalam surat Nota dinas VP of Corporate Safety Management PST PT Angkasa Pura No ND.9977/DSM/00/10/2020 tentang pengadaan Alat Pelindung Diri (APD) Covid-19di lingkungan Kerja PT Angkasa Pura II.

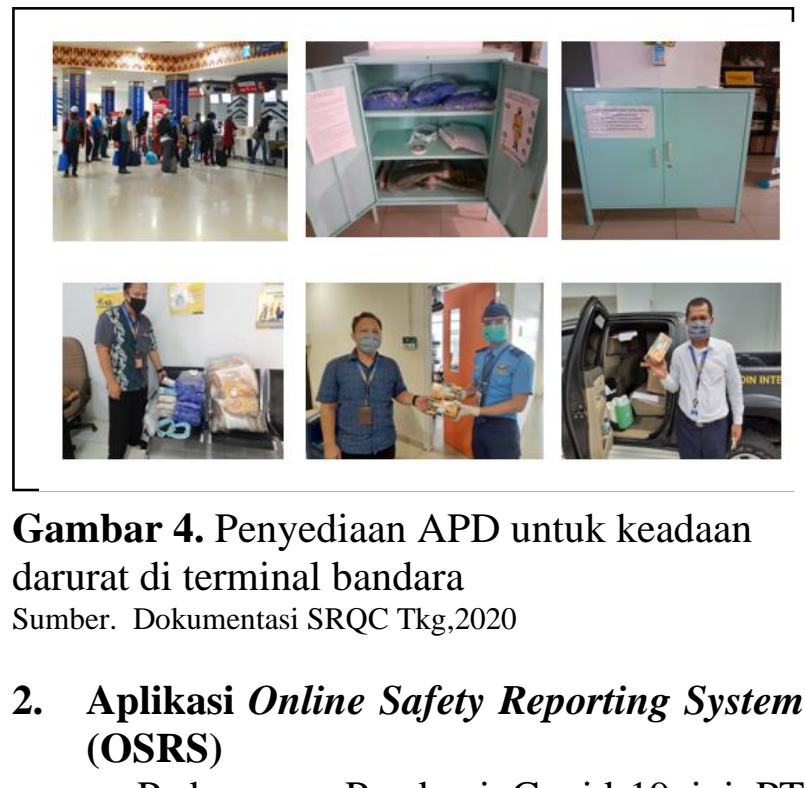

Pada masa Pandemi Covid-19 ini PT Angkasa Pura II turut memperkenalkan 
aplikasi yang saat ini dipakai utuk mengelola Safety Management System (SMS) yang mengelola pelaporan dan pengaduan masyarakat/ pengguna jasa bandara berbasis online, dan dirancang untuk mengelola laporan tersebut demi meningkatkan layanan keselamatan pada bandara yang dikelola PT Angkasa Pura II (persero), untuk ditindak lanjuti oleh pihak safety risk and quality control. Adapun link yang dipakai adalah www.angkasapura2.co.id/id/external internal Lsafety. Aplikasi OSRS merupakan hasil pengembangan yang berawal dari hanya sekedar media pelaporan menjadi media pengelolaan data keselamatan (database) yang terintegrasi dengan aplikasi Data Angkutan Udara (DAU), data Human Capital (HC) dan data pelaporan keselamatan melalui website sehingga penerapan system keselamatan PT Angkasa Pura II (Persero) menjadi lebih efektif dan efisien. Proses Bisnis Aplikasi OSRS: 1) Planning/ Perencanaan yaitu Proses ini adalah tahap awal ang dilakukan oleh Unit Pembina Safety Kantor Pusatdalam menetukan targettarget Kinerja Safety yang harus dicapai oleh Safety Kantor Cabang (KC). Kinerja Safety ini terbagi 2 yaitu Kinerja SMS dan Health Safety Environment (HSE). 2) Implementation / Pelaksanaan yaitu proses ini adalah tahap dari pelaksanaan indicator kinerja keselamatan baik itu kinerja SMS maupun HSE. Pada tahap ini safety Kantor cabang melakukan penginputan tindak lanjut internal audit, pelaporan pelaksanaan Runway Safety Team (RST). 3) Monitoring/ Pengawasan yaitu proses ini merupakan tahap verifikasi oleh unit Pembina Safety terhadap Proses Pelaksanaan yang dilakukan oleh Safety KC. Selain itu Unit Pembina Safety dapat melakukan monitoring terkait capaian Safety Performance Indicator (SPI), Accident Rate (AR), Frequency Rate (FR), dan Kinerja Safety Kantor Cabang. 4) Evaluation/ Evaluasi yaitu proses dimana unit Pembina Safety Kantor Pusat dapat melakukan evaluasi terhadap kinerja personil Safety KC dalam hal pengelolaan keselamatan bandara menggunakan Aplikasi OSRS. Untuk proses pencegahan (preventive) adalah pengukuran batas Ketinggian Bangunan di Kawasan Keselamatan Operasi Penerbangan (KKOP) dan batas Ketinggian Operasi Drone di KKOP.
Aplikasi KKOP merupakan media bagi masyarakat umum untuk memperoleh informasi awal batas ketinggian objek yang diizinkan di Kawasan Keselamatan Operasi Penerbangan (KKOP) bandara yang dikelola oleh PT Angkasa Pura II (Persero), sehingga dapat menjadi bahan pertimbangan dalam perencanaan pembangunan gedung atau objek yang dapat mengganggu keselamatan operasi penerbangan. Selain itu, pengguna aplikasi juga dapat melihat objek yang menjadi obstacle di KKOP. Tujuan Aplikasi KKOP ini adalah untuk mengajak masyarakat peduli terhadap keselamatan penerbangan di Kawasan Keselamatan Operasi Penerbangan (KKOP).

Sedangkan aplikasi No Drone Zone merupakan aplikasi untuk memberikan informasi bagi user batas ketinggian menerbangkan drone di Kawasan Keselamatan Operasi Penerbangan.

Untuk dapat mengoperasikan aplikasi OSRS ini PT Angkasa Pura II memberikan otorisasi kepada petugas Safety Risk and Quality Control sebagai admin pengelola aplikasi di setiap cabang. Dengan menggunakan aplikasi ini maka pengelolaan safety management system dapat terukur kinerjanya.

Angkasa Pura II memberikan panduan bagi administrator bagaimana mengoperasikan aplikasi tersebut dan terpantau melalui aplikasi I perform PT Angkasa Pura II. Untuk itu dapat membaca tentang masing-masing penanggung jawab diwajibkan mengikuti (seminar online) webinar yang diadakan oleh kantor pusat PT Angkasa Pura II pada tanggal 7 Maret 2020. Untuk 3 (tiga) bandara baru yang bergabung dengan PT Angkas Pura II masih belum begitu familiar dengan pengoperasian aplikasi ini terutama di masa pandemi Covid 19 ini, sosialisasi dan pelatihan dilaksanakan secara online melalui aplikasi zoom. Sehingga, butuh pelatihan langsung agar aplikasi ini dapat terpakai dengan baik. Namun secara bertahap aplikasi ini akan terpakai, karena sebagai indikator kinerja adalah pelaporan yang menggunakan aplikasi OSRS ini.

\section{Aplikasi Travelation.}

Melalui Gugus Tugas Covid-19 Pemerintah telah membuat aturan ketat terkait syarat-syarat melakukan perjalanan selama 
masa Pandemi Covid-19 berlaku sejak tanggal 7 Mei 2020 yaitu:

1. Perjalanan Dinas Lembaga Pemerintah dan Swsta dengan syarat-syarat yaitu:

a. Menggunakan Masker

b. Membawa identitas diri

c. Surat Tugas dari pimpinan

d. Surat Pernyataan Bermaterai

e. Menunjukkan hasil Rapid Test Negatif

f. Melaporkan rencana perjalanan dari keberangkatan hingga kepulangan

2. Perjalanan Pasien yang membutuhkan Pelayanan Kesehatan Darurat

a. Menggunakan Masker

b. Membawa identitas diri

c. Surat Rujukan dari Rumah Sakit

d. Menunjukkan hasil Rapid Test Negatif

3. Perjalanan Orang yang anggota keluarga intinya sakit keras. meninggal dunia

a. Menggunakan Masker

b. Membawa identitas diri

c. Surat Keterangan Kematian

d. Menunjukkan Hasil Rapid Tes Negatif

4. Repatriasai Pekerja Migran, WNI, Pelajar yang berada di Luar Negeri, serta pemulangan orang dengan alasan khusus oleh Pemerintah sampai ke daerah

a. Menggunakan Masker

b. Membawa identitas diri

c. Surat Keterangan dari Badan Pekerja Migran Indonesia

d. Surat keterangan dari Universitas/sekolah masing-masing jika pelajar/mahasiswa

e. Menunjukkan Hasil Rapid Tes Negatif

Namun sejak dikeluarkannya surat oleh Gugus Tugas Percepatan Penanganan Covid 19 Nomor SE No 7/2020, tentang Kriteria dan Persyaratan Perjalanan Orang Dalam Masa Adaptasi Kebiasaan Baru Menuju Masyarat Produktif dan Aman Covid-19 dimana dijelaskan bahwa untuk penumpang Domestik, maka syarat-syaratnya adalah:

1. Mematuhi Protokol Kesehatan dengan tetap memakai masker, menjaga jarak dan menerapkan pola hidup sehat/bersih.

2. Menunjukkan identitas diri (KTP/tanda pengenal lain yang sah)
3. Menunjukkan surat keterangan uji tes PCR negative (masa berlaku 7 hari) atau surat keterangan uji Rapid tes non reaktif (masa berlaku 3 hari) pada saat keberangkatan

4. Menunjukkan surat keterangan bebas gejala influenza

sedangkan untuk penumpang internasional persyaratan yang ada yaitu:

1. Mematuhi Protokol Kesehatan dengan tetap memakai masker, menjaga jarak dan menerapkan pola hidup sehat/bersih

2. Jika tidak dapat menunjukkan surat hasil PCR tes pada saat tiba di Bandar udara tujuan, maka penumpang wajib mengikuti prosedur PCR tes di bandara tujuan

3. Penumpang wajib menjalani masa karantina 14 hari dalam menunggu hasil uji PCR tes yang difasilitasi oleh pemerintah.

4. Memanfaatkan akomodasi karantina (hotel/penginapan) yang telah mendapatkan sertifikasi penyelenggara akomodasi karantina COVID-19 dari kementerian Kesehatan.

Diharapkan dengan dibuatnya tanda -tanda (sign) sebagai panduan kepada penumpang untuk mematuhi saran pemerintah yaitu $3 \mathrm{M}$,

Memakai Masker, Menjaga Jarak dan Mencuci Tangan dan Mempersiapkan diri dengan melampirkan surat pengantar bebas Covid-19 dari laboratoium yang terdekat untuk dilakukan validasi oleh pihak Kantor Kesehatan Pelabuhan serta mengisi High Alert Card (HAC) atau e-HAC, maka calon penumpang dapat berangkat dengan menggunakan pesawat udara. Pada saat turun di Bandar udara tujuan, maka penumpang pesawat udara akan diperiksa HAC nya atau eHAC dan suhunya oleh pihak Kantor Kesehatan Pelabuhan (KKP).

Aplikasi lain yang disediakan oleh PT Angkasa Pura II sebagai operator selama masa pandemi covid adalah Travelation. Dikutip dari laman kompas.com tanggal 26 Juni 2020, travelation adalah adalah aplikasi yang disediakan oleh PT Angkasa Pura II pada tanggal 7 Juni 2020 guna mempermudah penumpang yang akan berangkat dengan pesawat udara melakukan pengecekan dokumen perjalanan aplikasi ini bisa diakses dengan alamat www.travelation.angkasapura2.co.id. 
Aplikasi ini sangat berguna guna mengurangi kerumunan calon penumpang yang mengantri sebelum proses check in. Keefektifan aplikasi ini adalah mampu mengurangi antrian penumpang namun karena banyaknya persyaratan yang diberlakukan oleh satgas Covid 19, pada saat awal pandemi, menyebabkan berkurangnya penumpang yang akan berangkat melalui bandara, namun penumpang sangat mengapresiasi kehadiran aplikasi ini. Penerapan aplikasi ini pun sudah di lakukan di seluruh bandara PT Angkasa Pura II.

\section{Pembatasan Jam Operasi}

Berdasarkan Peraturan Menteri Perhubungan Nomor PM Nomor 18 Tahun 2020, yang menyatakan tentang pengendalian transportasi dalam rangka pencegahan penyebaran Corona Virus Disease 2019 (COVID-19) pada pasal 10 ayat 1 yaitu: Pengendalian transportasi yang mengangkut penumpang yang dimaksud dalam pasal 9 merupakan pembatasan jumlah penumpang pada sarana transportasi.

Dengan adanya peraturan ini maka, operator pada Bandar Udara Internasional Radin Inten II Lampung, melakukan langkahlangkah seperti: melaksanakan pembatasan jam operasional bandara, yaitu dari jam 10.00 sampai dengan 20.00, yang dinyatakan dengan dikeluarkannya surat NOTAM untuk perubahan jam operasional.

Saat penelitian ini dilaksanakan menurut Bapak Latif Nur Sasongko, selaku Asisstant Manager Airport of Operation and Services, mengatakan bahwa jam operasi Bandar Udara Internasional Radin Inten II sudah dimulai sejak pukul 06.00 sampai dengan 19.00 WIB dengan status Minimum Operation Level 1. Keadaan ini akan berubah jika sewaktu-waktu kondisi membaik

Pembatasan jumlah penumpang dengan penerapan physical distancing dilakukan dengan cara menbuat tanda - tanda seperti pemberian tanda di kursi penumpang di ruang tunggu, dan membuat tanda batas jarak sekitar 2 (dua) meter antrian di ruang check in.

\section{Safety and Healthy Campaign}

Dalam rangka memperingati hari Perhubungan tanggal 17 September 2020, PT Angkasa Pura II (persero) melalui Direktur
Utama Bapak Muhammad Awaluddin mencanangkan program Safety and Healthy Campaign Tahun 2020 yang merupakan program kampanye keselamatan yang bertujuan untuk:

a. Pemastian safe travel experience (pengalaman perjalanan yang safe) dengan tetap mengimplementasikan kebijakan perubahan regulasi maupun protocol kesehatan di tengah adaptasi kebiasaan baru

b. Peningkatan Pelayanan Transportasi udara yang selamat, aman, nyaman serta sehat

c. Upaya membangun kembali trust dan confidence bagi seluruh pengguna bandara dan pengguna moda transportasi udara.

d. Mewujudkan Indonesia maju pada sector transportasi di tengah tantangan pandemi global.

Kegiatan-kegiatan yang dilakukan dalam rangka safety and healthy campaign diantaranya adalah, pembagian masker kepada para mitra usaha dan pengunjung bandara, penyediaan tempat pengujian Rapid Test di area terminal bandara, penyediaan layanan desinfeksi dan sanitasi di seluruh area bandara, penyediaan layanan VICA (Virtual Customer Assistant), dan Kegiatan Ramp Inspection (pembersihan FOD, pemeriksaan GSE dan penempatan kendaraan non motorized).

\section{Wawancara Dengan Informan Penelitian}

Dalam penelitian ini kami mewawancarai para narasumber yang bertugas di Bandar udara Internasional Radin Inten II Lampung, tentang beberapa hal terkait faktor- faktor yang merupakan pendukung dan penghambat dalam rangka implementasi Safety Management System yang telah diterapkan selama ini. Bapak Dwija Ginting sebagai penanggung jawab Safety Risk and QC kantor Cabang Radin Inten II menyatakan bahwa "sosialisasi tentang Covid-19 ke penumpang seperti phisical distancing dan Penggunaan Hand Sanitiser sudah kita sosialisasikan lewat aviation security, namun memang kendala jam operasi dan jumlah personil yang sedikit sudah menjadi ketetapan manajemen untuk menjaga cash flow perusahaan. Pengurangan personil dan jam operasi yang sedikit ini menjadi kendala dalam sosialisasi sementara jumlah penumpang di bandara ini saya rasa cukup 
ramai dibandingkan dengan bandara lain Disamping itu struktur organiasi yang belum berkembang, masih mengikuti struktur yang lama menjadikan kita cukup kewalahan dimana satu assissmen manager membawahi sejumlah unit kerja". Disini dapat diketahui bahwa sosialiasasi keselamatan kepada penumpang selama di bandara sudah dilakukan, namun kendala pembatasan jam operasi dan kurangnya jumlah personil, menjadi kendala utama di bandara ini, disamping struktur oganisasi yang belum berkembang.

Bapak Latif Nur Sasongko selaku Assistant manager Operation and Services Kantor Cabang Radin Inten II Airport, menambahkan kendala itu memang benar adanya hal ini kita lakukan untuk mengamankan personil kita, kami sadar dengan keterbatasan jumlah kami, jika kami jor-jor an untuk meminta menambah personil standby terus menerus, maka efeknya dikhawatirkan yang terjadi adalah penurunan imunitas personil itu sendiri, sehingga potensi terjadi penularan menjadi lebih tinggi maka penerapan protocol kesehatan yang ketat itu yang kita jaga, dan Alhamdulillah kita mendapat support dari TNI AU dari KKP terkait penetapan protocol kesehatan dan sounding (mensosialisasikan) jaga jarak, penyampaian jaga jarak tersebut disampaikan setiap satu jam sekali melalui pengumuman dan penambahan jumlah 6 personil TNI AU sebagai bagian dari satgas Covid-19 untuk menambah jumlah personil dilapangan guna memantau pelaksanaan penerapan protocol kesehatan kepada masyarakat, karena tingkat kepatuhan dan kesadaran masyarakat yang masih dibawah rata-rata, untuk mengingatkan selalu pemakaian masker dan menjaga jarak. Dari sisi struktur organisasi kaitan safety hanya diisi satu orang memang menjadi tugas berat di kami namun kekompakan yang ada dikami, maka kami berusaha untuk bahu membahu berjalan. Dari sisi anggaran, dalam kondisi saat ini, memang terbatas, namun kami menganggap pemenuhan protocol kesehatan adalah kewajiban, maka kegiatan penyemprotan desinfektan, penyediaan hand sanitizer, penyediaan tempat pencucian tangan dan pemasangan tanda marka jaga jarak, tetap kami lakukan sebagai bentuk komitmen kami mencegah penularan covid-19. Pemerintah Daerah Provinsi Lampung juga mendukung kegiatan kami dengan cara melakukan penyemprotan desinfektan seminggu sekali dan bandara merupakan objek atau daerah yang ditunjuk, disini kami lihat perlunya sinergitas antar stake holder agar penanganan covid 19 ini membawa hasil yang baik. Di saat ini dari safety, tetap konsen dalam penyediaan APD, terutama personil melakukan pemeliharaan. Personil tetap memakai APD dan usaha yang sedang dan terus kita lakukan sosialisasi kepada personil untuk tetap memakai masker, menjaga jarak dan sebagainya adalah hal utama yang kita lakukan. Disamping itu keberadaan layang-layang yang ada disekitar bandara, namun sampai saat ini belum menjadi ancaman bagi penerbangan. PT AP 2 juga tetap konsen dalam penyediaan masker dan APD lainnya. Sosialisasi yang kita lakukan adalah seperti pada saat itu ada pagar pengamanan lingkungan ada yang terbuka, yang kami lakukan adalah membuat sosialisasi ke masyarakat dan mengingatkan untuk bermain layang-layang atau bermain drone disekitar Bandar udara. Dan kami juga mengikuti juga edaran-edaran yang yang dikeluarkan oleh Direksi AP 2 untuk selalu mematuhi aturanaturan keselamatan penerbangan.

Pada kesempatan lainnya, peneliti juga mendapatkan informasi Gugus Tugas Covid-19 yaitu Bu Arni dan Leli dari Kantor Kesehatan Pelabuhan Lampung, yang mengatakan bahwa pada masa covid ini, Bandar udara Radin Inten sudah menyediakan ruangan untuk pemeriksaan rapid tes, pemberian APD, secara umum sudah bagus dan aturan-aturan wajib masker ketika berada di bandar udara. Dan sebelum masuk ke bandara di ukur suhu tubuhnya, sedangkan kendala atau faktor penghambat adalah sulitnya mengatur jarak penumpang pada saat pemeriksaan eHAC, kemudian ada juga penumpang yang susah diatur dengan membuka masker, kemudian kurangnya informasi kepada penumpang dimana sebelum berangkat tidak membawa surat rapid. Kurangnya petunjuk berupa banner seperti cara mencuci tangan. Dari uraian yang disampaikan petugas diatas bahwa, saat ini kegiatan penanganan covid-19 sudah dilaksanakan dengan baik dan sesuai petunjuk, namun kendala yang ada adalah dari calon 
penumpang dan penumpang di awal - awal masa pandemi, yang belum dapat beradaptasi dengan aturan yang dikeluarkan oleh pemerintah diharapkan kedepannya sikap masyarakat dapat lebih baik lagi.

Wawancara juga dilakukan dengan bapak Eko Wahyu, TNI AU dari Satgas Covid, bahwa kami berbicara terkait pelaksanaan tim satgas covid 19, kami menganggap pelaksanaan pencegahan covid berjalan lancar dengan kendala-kendala yang masih bisa kami atasi secara baik. Pada saat proses arus penumpang baik datang maupun berangkat, kami tetap mensosialisasikan motto $3 \mathrm{M}$ yaitu: jaga jarak, pakai masker, cuci tangan, namun secara umum para penumpang sudah mengetahui, dan penumpang juga mengetahui untuk membawa dokumen hasil rapid tes jika ingin berangkat. Untuk faktor pendukung kegiatan kita juga sebagai sistem pengamanan (sispam) memback up avsec, oleh pihak bandara kita difasilitasi dengan APD masker, sarung tangan dan face shield dan beberapakali diadakan kegiatan rapid tes bagi karyawan, cuci tangan hand sanitizer sudah disediakan oleh bandara baik itu di keberangkatan dan kedatangan Untuk faktor penghambat ada beberapa penumpang yang tidak memakai masker atau memakai tetapi tidak sempurna, akan kita tegur, namun pelanggaran itu pun hanya beberapa saja dan kita melakukan tindakan secara persuasive.

Di tempat terpisah wawancara juga bersama Bapak Gerry Hendarsyah, sebagai Asisstant Manager Airport of Security and RFF PT Angkasa Pura II KC Radin Inten II, menjelaskan bahwa faktor pendukung dalam masa pandemi ini bahwa peraturan Direksi dan pihak manajemen sendiri aktif mengeluarkan peraturan-peraturan direksi yang berkaitan penerapan protokol kesehatan di Bandar udara, seperti pengadaan APD dan kelengkapan lain seperti masker sarung tangan dan lain sebagainya. Manajemen berkoordinasi dengan Ditkampen untuk mengurangi personil yang berdinas guna mengurangi interaksi dan mempertahankan daya tahan tubuh serta memberikan pengadaan vitamin-vitamin bagi petugas operasional.

Faktor penghambat kalau dulu sepertinya pada saat jam operasi baru dimulai, di saat personil avsec kita sudah siap, namun petugas dari instansi lain belum datang, sementara penumpang sudah menumpuk, yang kita khawatirkan adalah penumpukan penumpang yang dapat berpotensi menularkan covid. Namun setelah kita beberapa kali mengadakan rapat koordinasi, maka kendala tersebut dapat diatasi. Dengan adanya kesepakatan pada saat jam operasi para petugas itu dapat standby, disamping itu kita juga mendapat bantuan dari satgas covid yaitu, bantuan personil yang datang pada hari-hari tertentu sehingga membantu penanganan covid di bandara.

Kendala lain tidak ada karena memang kita menerapkan aturan bagi yang masuk ke bandara wajib memakai masker. Dukungan dari seluruh pihak sangat besar seperti pemerintah daerah dan satgas Covid. Menurut uraian Bapak Gerry diatas, menjelaskan bahwa kekhawatiran akan adanya penumpukan penumpang akibat dari ketidaksiapan personel dari petugas Kantor Kesehatan Pelabuhan yang tidak atau belum datang, maka yang diperlukan adanya sinergitas antara stakeholder di bandara agar pelayanan kepada penumpang tidak merasa dirugikan.

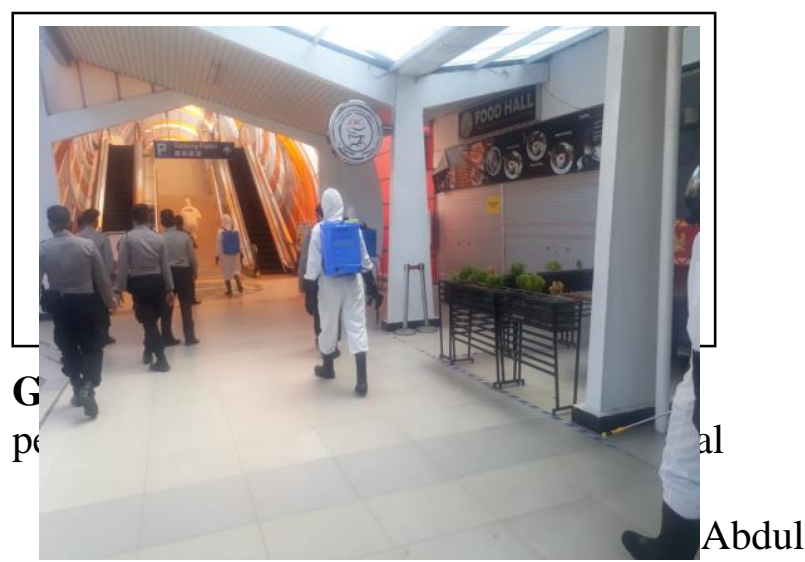

Hafidz sebagai Assistant Manager of Airport Maintenance Facilities mengatakan bahwa pada PT Angkasa Pura II ini untuk safety ada unit khusus sendiri yaitu Safety Risk Management, sebagai unit teknis, kami tetap mendukung/ support dalam pemenuhan unsur safety, kendala-kendala yang urgen dan membutuhkan biaya besar, tetap kita lakukan, namun pelaksanaannya dilaksanakan secara bertahap. Kami akan lakukan dengan nama program investasi namun apabila ada kendalakendala yang bisa kami tangani segera dan urgent maka akan kami lakukan, seperti 
patching (penambalan) lapisan runway, tetap kami lakukan demi menjaga performance fasilitas.

Untuk penerapan protokol kesehatan selama pandemi ini pada pekerjaan pemeliharaan tetap dilakukan secara penuh dan sesuai anjuran pemerintah. Faktor kendala biaya anggaran yang besar dalam pemeliharaan akan dilaksanakan secara bertahap. Dari uraian singkat diatas faktor biaya yang besar dalam pemeliharaan tetap akan diusulkan secara bertahap, namun saat ini pemeliharaan yang bersifat urgent dan bisa ditangani oleh teknisi lokasi tetap akan dilaksanakanan demi mempertahankan performance.

Hasil wawancara dengan Bapak RM Muhtadin, supervisor infrastructure facility menyatakan bahwa faktor pendukung penerapan Safety Management System, seperti pelaksanaan protokol kesehatan sudah disosialisasikan, seperti penyediaan masker bagi karyawan dalam pekerjaan sehari-hari dan penerapan Standard Operating Procedure (SOP) di wilayah airside dan land side, penyediaan hand sanitizer, yang saat ini masih ada dan arahan dari Executive General Manager (EGM) untuk tetap mematuhi protokol kesehatan. Saat ini tidak semua teknisi berada di area publik, dan apabila ada yang ke area publik seperti ke terminal, wajib menerapkan protocol kesehatan. Sedangkan faktor kendala yang dihadapi saat ini relative tidak ada, namun keterbatasan personil dalam pemeliharaan yang membuat sedikit kewalahan karena adanya pembatasan personil pada saat jam operasi, sehingga semua harus bekerja keras agar pekerjaan pemeliharaan fasilitas tetap berjalan normal, untuk kendala peralatan tidak ada kendala, sedangkan pada masa covid ini seringkali kami dapati layangan putus yang ada di dekat landasan. Dari paparan yang telah disampaikan oleh Bapak RM Muhtadin ini, bahwa pelaksanaan protocol kesehatan secara umum telah dilaksanakan terutama jika teknisi infrastructure berada di terminal area publik, namun untuk kendala-kendala kurangnya personil sangat terasa apabila sedang melaksanakan pemeliharaan accidential yang menuntut kecepatan dan ketepatan waktu pelaksanaan pemeliharaan terutama sekali bila terkendalacuaca. Sedangkan tingkat penemuan layang-layang yang berada lingkungan airsid, cukup menjadi perhatian.

Bapak Yoga Pranata sebagai Electrical Facility Supervisor menjelaskan tentang safety management system pada saat wawancara mengatakan bahwa sudah seharusnya diterapkan di bandara, namun dimasa pandemi ini ada hal baru yaitu kita harus melibatkan diri sehingga kita terlibat dalam kampanye penerapan protokol kesehatan, yang sudah ditetapkan pemerintah dan semua orang yang ada di bandara khususnya untuk selalu menerapkan protokol kesehatan seperti pakai masker, cuci tangan dan jaga jarak.

Kita juga membuat tanda-tanda (signs) seperti: menjaga jarak agar tertib, perusahaan juga terkena dampak yaitu salah satunya penurunan jumlah penumpang, maka kita juga membuat sosialisasi safety campaign, seperti membagikan masker kepada penumpang, memberikan himbauan, parade kampanye ke media-media yang ada di Lampung supaya masyarakat tidak khawatir menggunakan transportasi udara selama masih menerapkan protocol kesehatan, kita juga bekerja sama dengan Airline, Kantor Kesehatan Pelabuhan, untuk saling bersinergi dengan tetap memberikan pelayanan yang baik ke penumpang transportasi udara selama pandemi ini. Menurut Bapak Yoga Pranata, faktor penghambat tampaknya tidak ada, paling umum adalah masih lemahnya pengguna jasa dalam mematuhi protocol kesehatan, namun jika kita rajin mengingatkan ke pengguna jasa. Maka faktor penghambat ini akan hilang hal ini karena penerapan kebiasan baru memang membutuhkan waktu.

Dari apa yang telah disampaikan oleh Bapak Yoga ini, dapat dijelaskan bahwa himbauan pelaksanaan penerapan protokol kesehatan sudah dilaksanakan lewat langsung maupun tidak langsung seperti lewat media sosial, dan kampanye keselamatan tentang penerapan new normal (kebiasaan baru).

$$
\text { Tommi Pasaribu, Petugas Apron }
$$

Movement Control (AMC) dalam wawancaranya mengatakan faktor pendukung bahwa kami sebagai personel AMC pada PT Angkasa Pura II, setiap jam kami mengirimkan setiap jam laporan safety ke kantor pusat untuk melaporkan kondisi marka, keberadaan Foreigen Object Debris (FOD), kondisi 
helipad dan kondisi lampu-lampu Airfield Lighting (AFL) disekitaran apron kondisinya baik atau tidak, guna menunjang safety management system (SMS) selain itu penerapan SMS harus berasal dari personil masing-masing, karena kita sudah didukung dengan peralatan yang baik seperti mobil operasi, kamera pengawas, tinggal petugas AMC yang mempunyai kemauan penerapan safety itu sendiri. Untuk faktor penghambatnya adalah kita sama-sama tahu bahwa ini adalah masa-masa sulit, jika ada fasilitas rusak pelaksanaan perbaikan pasti akan dilakukan namun mungkin dilihat dari tingkat keparahannya hazard dan keprioritasannya. Kondisi saat ini adalah Provinsi Lampung, sudah memasuki musim penghujan, jadi diperlukan kewaspadaan dari masing-masing unit terkait menyiapkan personil untuk memantau jika ada genangan air (water ponding) dan lain sebagainya, untuk segera melaporkan ke pihak manajemen agar segera dilakukan perbaikan.

Menurut hasil wawancara diatas dengan Bapak Tomi Pasaribu, menyatakan bahwa seluruh karyawan wajib menimbulkan sikap waspada dan sikap siap siaga terhadap hazard dan resiko yang timbul selama masa pandemi ini. Seiring dengan masuknya musim hujan, peluang akan adanya hazard semakin tinggi sehigga perlu disiapkan langkah-langkah antisipasinya.

Dalam wawancara terakhir dengan Bapak Nurul Hidayat, dari Perwakilan Kantor Otoritas Bandara Kelas I Utama Soekarno Hatta mengatakan bahwa faktor pendukung protokol kesehatan terkait pencegahan covid sudah diterapkan di bandara ini seperti penyediaan hand sanitizer, masker dan lain sebagainya pun kerjasama dengan satuan Gugus Tugas Covid-19 pun sudah dilaksanakan. Narasumber yang merupakan Pegawai Kementerian Perhubungan secara khusus memuji kegiatan penanganan antisipasi penyebaran Covid-19 di bandara Radin Inten II Lampung dan berharap masa pandemi ini segera berakhir.

Beliau mengatakan saat ini, pelaksanaan kegiatan pemeliharaan peralatan masih dilakukan, pada saat pemeliharaan teknisi wajib memakai alat pelindung diri, seperti masker serta selalu mencuci tangan setelah melaksanakan kegiatan, hal ini dilakukan untuk melindungi karyawan dari potensi terpapar virus. Dalam penelitian ini peneliti mendokumentasikan beberapa kegiatan harian teknisi yang menerapakan protocol kesehatan.

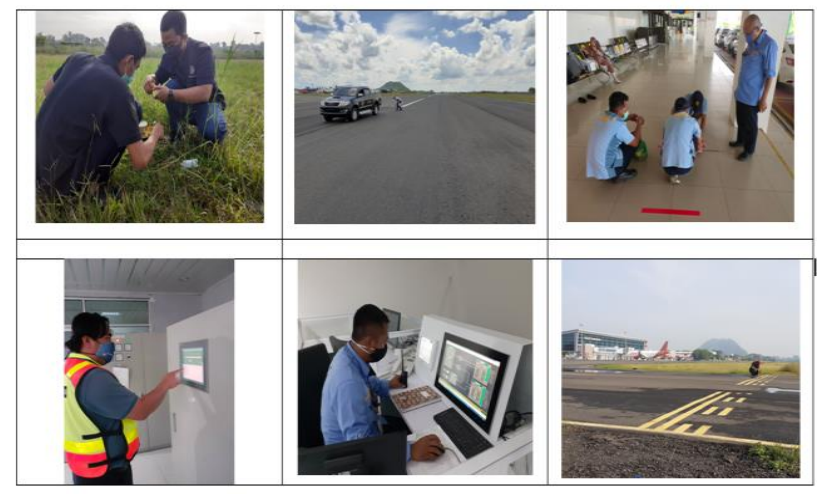

Gambar 6. Kegiatan Pemeliharaan Fasilitas di masa pandemi Covid-19

Sumber: Dokumentasi penelitian, 2020

\section{KESIMPULAN}

Dari hasil pelaksanaan penelitian ini diambil kesimpulan bahwa Implementasi Safety Management System di Bandar Udara Internasional selama masa pandemi Covid-19 PT Angkasa Pura II (Persero) Kantor Cabang Radin Inten II telah dilaksanakan secara baik, dengan tetap melaksanakan himbauan penerapan protocol kesehatan. Dengan selalu bersinergi dengan pihak lain dalam penanganan Covid-19 di bandara dan kesiapan operasional fasilitas baik itu sisi udara dan sisi darat merupakan faktor pendukung implementasi Safety Management System di Bandar Udara Internasional selama masa pandemi Covid-19, maka Bandar Udara Internasional Radin Inten II Lampung telah menyiapkan langkah-langkah antisipasi seperti:

a. Mengeluarkan kebijakan-kebijakan yang mendorong karyawan dan penumpang di bandara melaksanakan kebiasaan baru (new normal).

b. Menyiapkan fasilitas cuci tangan, hand sanitizer, dan desinfektan, dan pengkuran suhu tubuh sebagai antisipasi dalam mengatasi keadaan darurat.

c. Membuat aplikasi online safety reporting system report guna tetap menjaga bandara 
dalam on performance dalam hal keselamatan dan kenyamanan.

d. Bekerjasama dengan Kementerian Perhubungan dan satgas Covid-19 di Provinsi Lampung stake holder lainnya dalam upaya memutus penyebaran Covid19.

e. Melakukan pembatasan jam operasi bandar udara guna membatasi kerumunan manusia.

f. Menyediakan aplikasi online Travelation, guna mempermudah orang dalam pemeriksaan dokumen high alert card.

g. Penyediaan Alat Pelindung Diri (APD) bagi pegawai yang secara terus menerus dilakukan guna mempercepat kebiasan baru (new normal).

h. Melaksanakan kegiatan safety and healthy campaign yang bertujuan agar masyarakat tetap yakin dan percaya tentang penerbangan yang selamat, aman, nyaman dan sehat.

i. Memaksimalkan media social dalam upaya pemberian informasi dan edukasi kepada masyarakat terkait kegiatan transportasi udara.

Sedangkan untuk faktor penghambat implementasi Safety Management System di Bandar Udara Internasional Radin Inten II selama masa pandemi Covid-19 diantara adalah:

a. Kurangnya jumlah personil akibat pembatasaan jam operasi Bandar udara

b. Struktur Organisasi Bandar udara yang belum berkembang dimana belum sama dengan bandara lain menjadi kendala yang cukup berat di masa pandemi ini.

c. Meningkatnya keberadaan benda-benda di luar lingkungan bandara seperti layanglayang yang sering ditemui di sekitar bandara .

d. Konsistensi sosialisasi keselamatan secara internal maupun eksternal bandara tentang safety management system.

e. Pihak PT Angkasa Pura II melakukan efisiensi biaya dan operasi dalam rangka pemeliharaan fasilitas akibat pembatasan jam operasi, namun tetap melaksanakan pemeliharaan fasilitas yang bersifat urgent dan darurat.

f. Masih adanya pengguna jasa dan masyarakat yang melakukan pelanggaran protokol kesehatan.

\section{DAFTAR PUSTAKA}

Amalia,D,2019 "Promoting Just Culture For Enhancing Safety Culture In Aerodrome Airside Operation",International Journalof Scientific \& Technology Research,8(10),260-266

Chang, Y H, and friends, 2015 tentang Performance Evaluation Airport Safety Management in Taiwan tautan resmi https://tweb.cjcu.edu.tw/journal abstrac t/2015 $03 \quad 30 \quad 11 \quad 28 \quad$ 50.373.pdf Jurnal Safety Science, .diakses tanggal 11 September 2020

Distefano,N and Leonardi,S, 2013 Risk Assessment Procedure for Civil Airport,IJTE,ITALY tautan resminya di http://www.stradelandia.it/resources/PA PERS/2014 01.pdf jurnal luar negeri tanggal 11092020

Maulana,A,2020, Penerapan Komunikasi Pemasaran Pada Complaint Delay di PT Angkasa Pura II Bandara Internasional Minangkabau, Universitas Andalas, Padang, diakses 29 Desember 2020 , http://www.scholar.unand.ac.id

Martadinata,MI, Analisis Safety Management System di Bandar Udara Internasional Radin Inten II Lampung, Universitas Bandar Lampung, Lampung, 2020

Nurrasjid MN,2011 Jurnal Penelitian Penerapan Sistem Manajemen Keselamatan di Bandar Udara Sepinggan Balikpapan tautan resmi https://media.neliti.com/media/publicati ons/234123-penerapan-sistemmanajemen-keselamatan-s-78b7163a.pdf diakses tanggal 11 September 2020

Raman,R Chidambara,2010, Problem and Solution in the Implementation of Safety 
Management System, ACI Asia-Pacific Young of the Year Award Submission, India

Raofi,Azzam and Friend,2020, tentang Covid19 Pandemic comparative health policy learning, Jurnal Iranian Medicine,Iran tanggal april 2020, tautan resmi http://www.aimjournal.ir/PDF/aim-23220.pdf diakses tanggal 11 September 2020

Rai,AAG,2012, Sistem Manajemen eselamatan Yang Terintegrasi di Apron Bandar Udara, Jurnal Universitas Indonesia, diakses tanggal 11 September 2020

Suprapto,H, Metodologi Penelitian untuk Karya Ilmiah, Gosyen Publishing, Yogyakrta,2017

Sugiyono, Metode Penelitian, Kuantitatif, Kualitatif dan R\&D, Alfabeta, Bandung,2019

Tahrus,2020, Dunia Dalam Ancaman Pandemi : Kajian Transisi Kesehatan Dan Mortalitas Akibat Covid-19, ReserchGate Journal Diakses, 11 -09- 2020

Tri Cahyani,dkk, "Rancangan Monitoring Peralatan Trasmitter Very High Frequency PAET6T Berbasis WebServer", Journal of Airport Engineering Technology (JAET),2021

Yarlina,L”Evaluasi Kondisi Fasilitas Terminal Bandara Raden Inten II Untuk Peningkatan Pelayanana Penumpang dan Sebagai Pemenuhan Syarat Sebagai Embarkasi Haji”, Warta Ardhia,2017

SariWT,dkk,"Edukasi Kesehatan Protokol Pencegahan Covid-19 dan Penyerahan Bantuan Sembako di Panti Asuhan AsSalam Kota Pekanbaru", Jurnal Abdimas, 2020

Amalia,D, dkk"Pelatihan Basic Human Factor Self Awareness dan Safety Culture Petugas Operasi Bandar Udara Gusti Syamsir Alam, Darmabakti Jurnal Inovasi Pengabdian dalam Penerbangan, 2020

Nugraha,W.,dkk"Pelatihan Safety Management System bagi Pegawai Unit Penyelenggara Bandar Udara Gusti Syamsir Alam Kotabaru",Darmabakti: Jurnal Inovasi Pengabdian dalam Penerbangan, 2020
Dokumen publikasi dari ILO,2020 tentang Dalam menghadapi Pandemi : Memastikan Keselamatan dan Kesehatan di Tempat Kerja, tautan resmi : https://www.ilo.org/wcmsp5/groups/pub lic/---asia/---ro-bangkok/---ilojakarta/documents/publication/wcms 74 2959.pdf unduhan tanggal 11 September 2020

Gugus tugas covid 19,2020, Pedoman Penanganan Cepat dan Kesehatan Masyarakat COVID-19 di Indonesia, BNPB, Jakarta

HSG268,2014,The Health and Safety Toolbox How to control risk at work, www.nationalarchives.gov.uk/doc/opengovernment-licences

Pedoman dari EASA terkait covid-19, 2020 tautan resminya adalah https://g8fip1kplyr33r3krz5b97d1wpengine.netdna-ssl.com/wpcontent/uploads/2020/05/EASAECDC COVID-19.pdf, diakses tanggal 11 september 2020

Stolzer JA dan Goglia JJ, 2015, Safety Management System

Aviation,England,ASHGATE

Berita BBC.com tanggal 8 April 2020, tentang Gelombang PHK terjadi pada Bulan Juni, kartu prakerja dianggap tak efektif tautan resminya

https://www.bbc.com/indonesia/indonesi a-52218475 diakses tanggal 11 September 2020

Berita dari ETcio.com, tanggal 14 April 2020, tentang Covid-19: 8 ways in which technology helps pandemic management, tautan

resmi

https://cio.economictimes.indiatimes.co $\mathrm{m} /$ news/next-gen-technologies/covid-19-

8-ways-in-which-technology-helpspandemic-management/75139759, diakses tanggal 11 september 2020

Berita Online Sonora.id tanggal 17 April 2020 tentang Gubernur Lampung tak akan 
terapkan PSBB , tautan resmi https://www.sonora.id/read/422110444/ tak-akan-terapkan-psbb-gubernurlampung-karena-tidakmenguntungkan?page=all

Berita online Pripos.id tanggal 21 Juli 2020, tentang Menhub Ajak Stakeholder penerbangan ciptakan penerbangan yang selamat, aman dan sehat, tautan resmi https://pripos.id/menhub-ajak-seluruhstakeholder-penerbangan-ciptakanpenerbangan-yang-selamat-aman-dansehat/

Oktiani,vina,2020,Asal Mula Virus Corona, Artikel Wolipop,

http://wolipop.detik.com/health-anddiet/d-4946027/apa-yang-dimaksudvirus-corona-ini-asal-mula-hingga-gejalawww.kompas.com/panduanpenggunaan aplikasi pemeriksaan dokumen penumpang pesawat, diakses tanggal 26 April 2020

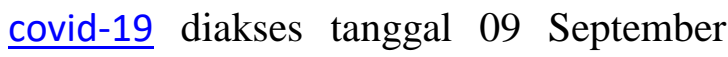
2020

Informasi tentang covid-19 di situs online https://covid19.lampungprov.go.id/

ICAO, 20209, Annex 19 tentang Safety Management System Manual(SMM),Doc 9859,AN 474, second edition, International Civil Aviation Organization

Aplikasi OSRS Angkasa Pura 2 www.angkasapura2.co.id/id/external_internal/s afety.

Surat Edaran Menteri Perhubungan Republik Indonesia Nomor SE 13 Tahun 2020 tanggal 8 Juni 2020, tentang Operasional Transportasi Udara Dalam Masa Kegiatan Masyarakat Produktif dan Aman Dari Corona Virus Disease $2019 \quad$ (Covid-19) 